can be compatible if environmental impact assessments are properly made in the early planning stages."

'Secondly, it shows that in a democracy a misguided Government cannot ignore the will of an informed and vigilant public. The conservation movement must be constantly on guard and take every legal remedy to stop environmental abuse, no matter how powerful the offender may be.'

'We have won, at least temporaily, at Hainburg. We won at the proposed Franklin Dam in Tasmania, Australia. But at many other important sites around the world where devel- opment is proceeding heedless of sound conservation, we will lose unless the issues are publicized and people are mobilized to defend their natural heritage, as at Hainburg', Dr Hoffmann concluded.
David Mitchell
WWF Director of Development \& Public Affairs
World Conservation Centre
Avenue du Mont-Blanc
1196 Gland, Switzerland.

\title{
Scientists to Study How Increased Human Activity in Alaska Will Affect Nearby Seas
}

An international study is being launched to learn how increased fishing, oil and gas drilling, and farming, will affect marine life in the pristine ocean waters bordering northern Alaska. Studies already conducted suggest that, despite the short growing-season, the seas around Bering Strait produce more plant life than most other marine areas. Still, the sources of mineral nutrition for this plant life, and its destination either as part of a food-web or as organic sediment, are only poorly known.

Physical oceanographers, chemists, and biologists, from the United States, Belgium, and Denmark, will study the fate of nutrients introduced from the Yukon River into waters above the continental shelves of the Bering and Chukchi (Chukotskiy) Seas and into the deeper waters of the Bering Sea. The two-years', $\$ 2.5$ millions effort will be funded by the US National Science Foundation's Division of Polar Programs and headed by Dr C. Peter McRoy, of the University of Alaska.

Scientists from the Universities of Alaska, Washington,
Southern Florida, and Texas, and from the Brookhaven National Laboratory, will participate in the project called ISHTAR - for Inner Shelf Transfer and Recycling in the Bering and Chukchi Seas. Also participating will be workers from the University of Liège in Belgium and the University of Århus in Denmark.

The project is considered of special importance because it has both basic and applied research values, being designed to gain a basic understanding of what happens to land and marine organic matter when it enters this continental shelf system. Improved understanding will enable scientists to predict future responses of this shelf system to proposed increases in fishing, in oil and gas drilling, and in the cultivation of 500,000 acres $(202,500 \mathrm{ha})$ in the Yukon River drainage basin.

National Science Foundation $1800 \mathrm{G}$ Street

Washington

DC 20550, USA.

\section{Review Conference of the Convention Prohibiting Hostile Use of Environmental Modification Techniques*: Final Declaration}

\section{Purposes}

The States Parties to the Convention reaffirm their strong common interest in preventing the use of environmental modification techniques for military or any other hostile purposes. They reaffirm their strong support for the Convention, their continued dedication to its principles and objectives, and their commitment to implement effectively its provisions.

\section{Article I}

The Conference confirms that the obligations assumed under Article I have been faithfully observed by the States Parties. The Conference is convinced that the continued observance of this Article is essential to the objective, which all States Parties share, of preventing military or any other hostile use of environmental modification techniques.

Having re-examined the provisions of paragraph 1 of Article I, the Conference is convinced that, taking into account the relevant understandings and the present state of technology, they remain effective in preventing the dangers of military or any other hostile use of environmental modification techniques. The Conference recognizes the need to keep under continuing review and examination the

* This first Review Conference of the Convention was held in the Palais des Nations, Geneva, Switzerland, during 10-21 September 1984, under the Chairmanship of Keijo Korhonen, of Finland. - Ed. provisions of paragraph 1 of Article $I$, in order to ensure their continued effectiveness, taking into account any developments which might take place in the relevant technology, and having regard also to the different views expressed in the course of the debate on this Article on the question of expanding its scope.

\section{Article II}

The Conference reaffirms its support for this Article containing the definition of the term "environmental modification techniques'. The Conference is of the opinion that this definition, ${ }^{\dagger}$ taken together with the understandings relating to Articles $I$ and $I I$, is adequate to fulfil the purposes of the Convention.

\section{Article III}

The Conference reaffirms that Article III is without prejudice to any rules of international law which may apply to environmental modification techniques used for peaceful purposes. The Conference notes with satisfaction that the implementation of the Convention has not hindered the economic or technological development of States Parties. The Conference recalls that States Parties have undertaken to facilitate the fullest possible exchange of scientific and

\footnotetext{
$\dagger$ 'Any technique for changing - through the deliberate manipulation of natural processes - the dynamics, composition, or structure, of the Earth, including its biota, lithosphere, hydrosphere, and atmosphere, or of outer space.'-Ed.
} 
technological information on the use of environmental modification techniques for peaceful purposes.

The Conference further calls upon States Parties also to provide and facilitate the fullest possible exchange of scientific and technological information on the research on, and the development of, such environmental modificaiton techniques. Furthermore, and in order to ensure the widest possible exchange of such information, the Conference invites the Secretary-General of the United Nations to receive such information for dissemination. For this purpose, the Conference requests the Secretary-General to utilize to the maximum extent the United Nations agencies with competence in environmental topics.

The Conference also calls upon States Parties in a position to do so, to continue to contribute to and strengthen, alone or together with other States or international organizations, international economic and scientific cooperation in the preservation, improvement, and peaceful utilization, of the environment, with due consideration for the needs of the developing areas of the world.

\section{Article IV}

The Conference notes the provisions of Article IV, which requires each State Party to take any measures it considers necessary in accordance with its constitutional processes, to prohibit and prevent any activity in violation of the provisions of the Convention anywhere under its jurisdiction or control, and invites States Parties which have found it necessary to enact specific legislation, or take other regulatory measures relevant to this Article, to make available the appropriate texts to the United Nations Department of Disarmament Affairs, for the purposes of consultation.

\section{Article $V$}

The Conference notes with satisfaction that no State Party has found it necessary to invoke the provisions of Article $\mathrm{V}$ dealing with international complaints and verification procedures. The Conference reaffirms the importance of paragraph I of this Article, which contains the undertaking of States Parties to consult one another and to cooperate in solving any problems which may arise in relation to the objectives of, or in the application of the provisions of, the Convention, and of paragraph 2 , which provides for the convening of a Consultative Committee of Experts. In the view of the Conference the provisions of Article V, paragraphs 1 and 2, do not exclude the possibility of consideration, by States Parties, of the summary of findings of fact of the Consultative Committee of Experts.

The Conference also notes the importance of Article V paragraphs 3 and 4, which, in addition to the procedures contained in Article V paragraphs 1 and 2, provide that any State Party which finds that any other State Party is acting in breach of its obligations under the Convention, may lodge a complaint with the United Nations Security Council, and under which each State Party undertakes to coop- erate in carrying out any investigation which the Security Council may initiate.

The Conference considers that the flexibility of the provisions concerning consultation and cooperation on any problems which may arise in relation to the Convention, or in the application of the provisions of the Convention, should enable complaints or disputes to be effectively resolved.

\section{Article VI}

The Conference notes that during the operating of the Convention, no State Party has proposed any amendments to this Convention under the procedures laid down in this Article.

\section{Article VII}

The Conference reaffirms that the Convention should be of unlimited duration.

\section{Article VIII}

The Conference notes with satisfaction the spirit of cooperation in which the Review Conference was held. The Conference, recognizing the importance of the review mechanism provided in Article VIII, decides that a second Review Conference may be held in Geneva at the request of a majority of States Parties not earlier than 1989. If no Review Conference is held before 1994, the Depositary is requested to solicit the views of all States Parties concerning the convening of such a Conference in accordance with Article VIII paragraph 3 of the Convention.

\section{Article IX}

The Conference stresses that the six years which have elapsed since the date of entry into force of the Convention, have demonstrated its effectiveness.

The Conference notes that 45 States have become Parties to the Convention and a further 19 States have signed but have yet to ratify the Convention. The Conference notes with concern that the Convention has not yet achieved universal acceptance. Therefore the Conference calls upon all signatory States which have not ratified the Convention to do so without delay, and upon those States which have not signed the Convention to adhere to it as soon as possible and thereby join the States Parties thereto in their efforts to prohibit effectively military or any other hostile use of environmental modification tecnhiques. Such adherence would be a significant contribution to international confidence and to the strengthening of trust amongst nations.

INFORMATION SERVICE

United Nations Office at Geneva Palais des Nations

1211 Geneva 10

Switzerland.

\section{The Huge Bird-cliff, Látrabjarg, in Western Iceland*}

Bird-cliffs are fascinating places in more ways than one. Thus they often form the most spectacular stretches of rugged and exposed coasts, while the large numbers of noisy and conspicuous birds inhabiting them seldom fail to

* The main text was circulated unedited in mimeographed form by the European Information Centre for Nature Conservation, Council of Europe, B.P. 431 R6, 67006 Strasbourg, France, to whom our gratitude is due for this and other notable 'Environment Features'.-Ed. impress the observer. At the higher latitudes there is, in addition, the sharp contrast between a bleak hinterland and the teeming life of the bird-cliff. ${ }^{\dagger}$

One such place is Látrabjarg, on the westernmost tip of Iceland. The size of this cliff is such that it is difficult to

${ }^{\dagger}$ See, for example, our The Isle of Auks (Edward Arnold, London, England, UK: 253 pp., illustr. 1932) and 'The Vegetation of Akpatok Island, Part II' (Journal of Ecology, XXIII, pp. 161-209, figs and photos, 1935).-Ed. 